\title{
Profile of medicines used via oral and gastrointestinal catheter in a Walk-in Service*
}

\author{
Perfil dos medicamentos utilizados via oral e por sonda \\ gastroenteral em um serviço de pronto atendimento \\ Perfil de los fármacos utilizados por vía oral y por sonda \\ gastroentérica en un servicio de urgencias
}

Moara Avila de Jesus Moreira ${ }^{1}$, Paula Pereira de Figueiredo ${ }^{1}$, Rosemary Silva da Silveira ${ }^{1}$, Valdecir Zavarese da Costa ${ }^{2}$, Eliana Cardia de Pinho ${ }^{3}$, Miriã Soares de Bittencourt Coutinho ${ }^{1}$

How to cite this article:

Moreira MAJ, Figueiredo PP, Silveira RS, Costa VZ, Pinho EC, Coutinho MSB. Profile of medicines used via oral and gastrointestinal catheter in a Walk-in Service. Rev Esc Enferm USP. 2018;52:e03385. DOI: http://dx.doi.org/10.1590/S1980-220X2017037103385

* Extracted from the dissertation: "Medicações utilizadas por via oral e sonda gastroenteral em um Serviço de Pronto Atendimento: perfil e cuidados", Programa de Pós-

Graduação de Enfermagem, Universidade Federal do Rio Grande, 2017.

1 Universidade Federal do Rio Grande, Rio Grande, RS, Brazil.

${ }^{2}$ Universidade Federal de Santa Maria, Santa Maria, RS, Brazil.

3 Instituto Federal de Educação, Ciência e Tecnologia do Rio Grande do Sul, Campus Rio Grande, Rio Grande, RS, Brazil.

\begin{abstract}
Objective: To identify the profile of drugs prescribed via oral and gastrointestinal catheter in a Walk-in Service of a University Hospital. Method: Quantitative cross-sectional study in which data were collected from the medical records of hospitalized patients using medication via oral or gastrointestinal catheter at least once a day between April and October 2015. The analysis was performed through descriptive statistics. Results: Out of 568 prescriptions (total), there were 143 different medications. The pharmaceutical form with the greatest number of prescriptions was solid (95.8\%), of which $46.1 \%$ were simple tablets. The oral route had the highest number of administrations (97.3\%). The most prescribed drug class was of anti-infectives (25.9\%), but the Omeprazole drug was the most prescribed in the study (40\%). Conclusion: There are indications that enable rethinking the care practice and establishing criteria and norms for contributing to the safety and efficacy of services provided in healthcare, especially regarding the preparation and administration of medications via gastrointestinal catheter.
\end{abstract}

DESCRIPTORS

Enteral Nutrition; Patient Safety; Drug Interactions; Food-Drug Interactions; Nursing Care.
Corresponding author:

Moara Avila de Jesus Moreira

Universidade Federal do Rio Grande

Rua General Osório $\mathrm{s} / \mathrm{n}^{\circ}$, Campus da Saúde

CEP 96201-900 - Rio Grande, RS, Brazil

moarajesus@yahoo.com.br
Received: 10/17/2017

Approved: 05/24/2018 


\section{INTRODUCTION}

The National Patient Safety Program was established in 2013 by the Ministry of Health in order to improve the quality of health services through monitoring and prevention of damages to health care, and through promotion, implantation and implementation of initiatives focused on patient safety ${ }^{(1)}$. The proportion of avoidable events is globally led by Brazil, compared to countries such as New Zealand, Australia, Spain, Denmark, Canada and France ${ }^{(2)}$. Patient safety is an essential component of quality of care, one of the primary concerns in health services.

Even in the face of these efforts, there are difficulties in implanting a culture that encourages and rewards the identification, reporting, and resolution of problems related to patient safety. Unfortunately, in the occurrence of adverse events or errors, the punitive approach is present in daily care. However, this approach should be avoided given its ineffectiveness for combating human failures ${ }^{(3-4)}$.

Among the goals advocated by the World Health Organization are the safe preparation and administration of medicines. In recent years, medication errors have been identified as determinants of potential harm to patients ${ }^{(3)}$. The causes of errors are usually systemic and have multiple origins, namely: disorganized work environment, lack of attention/concentration, communication failure, lack of information about medications and the patient. In this context, a study pointed nursing as responsible for $46.4 \%$ of errors in drug therapy, in which administration was considered the phase with the highest incidence of errors (35.5\%). However, physicians and pharmacists are also involved in the occurrence of medication errors, and deemed responsible for $32.4 \%$ and $19.4 \%$ (respectively) of the errors initially evaluated in the aforementioned study. Consequently, the phases of prescription and distribution of drugs corresponded to percentages of $34.5 \%$ and $19.6 \%$ (5).

Given the complexity of the medication system, errors can occur in the prescription, distribution, preparation and/or administration of medications, and even in patient monitoring ${ }^{(6)}$. Studies have shown the recurring insecurity to which patients are exposed ${ }^{(7-8)}$. The scarcity of information on the subject in the scientific literature and from drug manufacturers themselves, makes it difficult to decide on the appropriate behavior to be adopted.

In medical prescription, the use of illegible letter, incomprehensible abbreviations, and the lack of standardization of the names and doses of medications are concerning factors. Drug dispensing at doses other than those prescribed is also a contributing factor to the occurrence of error in drug administration $^{(8-9)}$. However, in most cases, it is in the final stage of the medication process that the error not detected in previous steps is attributed exclusively to the nursing team.

Among routine activities of the nursing team, medication administration alone deserves special attention. Performing this care requires scientific knowledge and technical skills. In emergency and urgency services, patient safety requires greater visibility and attention. Due to the atypical context of assistance in Walk-in
Services (Portuguese acronym: SPA - Serviço de Pronto Atendimento), medication administration by gastrointestinal catheter (GIC) may be an alternative way to oral route given patients' worsening clinical conditions.

However, if inadequately performed, drug administration by this route may result in catheter obstruction, decreased drug efficacy, increased adverse effects or drug incompatibility with enteral nutrition (EN). These factors cause harm to patients, increase costs for the institution and burden the responsible team's work ${ }^{(3,5,9-10)}$.

Given this context, knowing the profile of drugs prescribed via oral and GI catheter in an Walk-in Service becomes relevant for patient safety. If medications are accurately checked, protocols can be established in order to assist in the adequate preparation and safe administration of medications via GI catheter according to the reality of each institution. It is reasonable to extend the survey to medications prescribed orally with the view of constructing a consolidated profile of the most frequently used drugs. Therefore, the objective is expanding the specific recommendations to the greatest possible number of drugs of the service routine and that are potentially prescribed via GI catheter if the patient's clinical situation requires it.

The objective of this study was to identify the profile of the most frequently prescribed drugs via oral and via GI catheter in the Walk-in Service of a University Hospital (UH) in Southern Brazil.

\section{METHOD}

\section{TYPE OF STUDY}

This is a quantitative cross-sectional study.

\section{SCENARIO}

It was conducted in the Walk-in service of a University Hospital linked to a Federal University in the extreme south of Brazil. This is a reference hospital in several specialties and services in the region, and care is provided exclusively through the National Health System (Portuguese acronym: SUS - Sistema Unico de Saúde). It is a large hospital with 20 beds available in the Walk-in Service. Despite this number, the unit has an expressive number of beds located in the corridors, because patients stay for a long time in this place waiting for a vacancy in an inpatient unit.

\section{Data collection}

Prescriptions of medication therapy of patients hospitalized in the Walk-in Service of the aforementioned University Hospital from April to October 2015 are the object of study. The inclusion criterion of prescriptions was having at least one drug administered via oral and/or GI catheter with fixed regimen. Data collection was performed once a week, totaling 27 weeks, with a specific form in which data were gathered regarding the date of admission, medication name, form of presentation, dose, route and administration regimen of the prescribed medication. Descriptive statistics were used to describe and synthesize data ${ }^{(11)}$. 


\section{ANALYSIS AND PROCESSING OF DATA}

A database was constructed in the SPSS (Statistical Package for Social Sciences), version 21.0, in order to perform descriptive analysis of the absolute and relative frequency of medicines, administration routes via oral and GI catheter, and the most used regimens in this service. The Medication Standardization Manual (2014) prepared at the University Hospital was used to check the standardized drugs in the institution and to classify the prescribed drugs according to their class (group of action).

\section{ETHICAL ASPECTS}

This study was conducted with approval of the Research Ethics Committee in Health of the local University, approved under opinion number 017/2015, and the ethical principles of Resolution 466/12 of the National Health Council were followed.

\section{RESULTS}

During the data collection period, 568 valid prescriptions were found, and an average of 8.5 days of hospitalization in the Walk-in Service, ranging from a minimum of 1 day to a maximum of 62 days. The mean was 2 days of hospitalization, which corresponded to a frequency of $82 \%$.

Of the total of 568 prescriptions, 143 different drugs were prescribed, prescribed at fixed times, via oral or GI catheter. Of these, most were prescribed in the solid form (95.8\%), and liquid presentations had a lower frequency (4.2\%). The various prescribed forms found in the study are shown in Table 1.

Table 1 - Frequency of pharmaceutical forms of the 143 drugs prescribed for patients via oral or gastrointestinal catheter in the Walk-in Service - Rio Grande, RS, Brazil, 2017.

\begin{tabular}{lcc}
\hline \multirow{2}{*}{ Pharmaceutical form } & \multicolumn{2}{c}{ Frequency } \\
\cline { 2 - 3 } & $\mathbf{n}$ & $\%$ \\
\hline Simple tablet & 66 & 46.1 \\
Coated tablet & 48 & 33.6 \\
Hard gelatin capsule & 10 & 7 \\
Soft gelatin capsule & 5 & 3.5 \\
Dragee & 4 & 2.8 \\
Oral solution & 3 & 2.1 \\
Syrup & 2 & 1.4 \\
Granulated powder & 2 & 1.4 \\
Emulsion & 1 & 0.7 \\
Sublingual tablet & 1 & 0.7 \\
Chewable tablet & 1 & 0.7 \\
\hline Total & $\mathbf{1 4 3}$ & $\mathbf{1 0 0}$ \\
\hline
\end{tabular}

After analysis, there were 1,742 drug administrations, when considering the different prescribed regimens. All 143 medications were orally administered, and this route accounted for the highest number of administrations. Twenty-four medications were explicitly administered via gastrointestinal catheter. It was not possible to detect the route of administration on 22 occasions (Table 2), which demonstrates an error in this stage of the process. Data available in the prescriptions may differ from the route of drug administration used by patients, since they were not observed. There may be a sudden worsening of the clinical picture, and the medication prescription may not have been immediately updated. Hence there may be divergence in these data, which justifies the care with preparation of medications to be administered via GI catheter.

Table 2 - Frequency of the route and administration regimen of medication used in the Walk-in Service - Rio Grande, RS, Brazil, 2017.

\begin{tabular}{|c|c|c|c|c|c|}
\hline \multirow{2}{*}{$\begin{array}{l}\text { Administration } \\
\text { route }\end{array}$} & \multicolumn{2}{|c|}{ Frequency } & \multirow{2}{*}{$\begin{array}{l}\text { Administration } \\
\text { regimen }\end{array}$} & \multicolumn{2}{|c|}{ Frequency } \\
\hline & $\mathrm{n}$ & $\%$ & & n & $\%$ \\
\hline \multirow{3}{*}{ Oral } & & & 1x/day & 987 & 56.7 \\
\hline & 1,696 & 97.3 & $12 / 12 \mathrm{~h}$ & 390 & 22.4 \\
\hline & & & $8 / 8 \mathrm{~h}$ & 257 & 14.7 \\
\hline \multirow[t]{2}{*}{$\begin{array}{l}\text { Gastrointestinal } \\
\text { catheter }\end{array}$} & 24 & 1.4 & $6 / 6 h$ & 70 & 4 \\
\hline & & & $4 / 4 \mathrm{~h}$ & - & - \\
\hline \multirow[t]{2}{*}{ Unknown } & 22 & 1.3 & $7 / 7$ days & 12 & 0.7 \\
\hline & & & Unknown & 26 & 1.5 \\
\hline Total & 1,742 & 100 & Total & 1,742 & 100 \\
\hline
\end{tabular}

After this characterization of medicines used in the Walk-in Service according to the form of presentation, route and regimen, these were classified by class (Table 3) according to the Medication Standardization Manual (2014) of the institution under study.

Table 3 - Medications used via oral and gastrointestinal catheter in the Walk-in Service according to class - Rio Grande, RS, Brazil, 2017.

\begin{tabular}{lcc}
\hline \multirow{2}{*}{ Medication } & \multicolumn{2}{c}{ Frequency } \\
\cline { 2 - 3 } & $\mathbf{n}$ & $\%$ \\
\hline Anti-infective & 37 & 25.9 \\
Drugs acting on cardiovascular system & 34 & 23.8 \\
Drugs acting on central nervous system & 25 & 17.5 \\
Drugs acting on digestive system & 12 & 8.4 \\
Analgesics & 6 & 4.2 \\
Others & 6 & 4.2 \\
Anti-inflammatory & 5 & 3.5 \\
Drugs acting on hematopoietic system & 5 & 3.5 \\
Drugs acting on endocrine system & 5 & 3.5 \\
Nutrients & 4 & 2.7 \\
Antiallergics & 2 & 1.4 \\
Drugs acting on respiratory system & 2 & 1.4 \\
\hline Total & $\mathbf{1 4 3}$ & $\mathbf{1 0 0}$ \\
\hline
\end{tabular}

The expressive group of anti-infective drugs accounted for $25.9 \%$ of the total prescriptions. The most prescribed among them were the following: Sulfamethoxazole + Trimethoprim, Azithromycin, Clarithromycin, Fluconazole, Sulfadiazine, Pyrimethamine.

For a more specific and in-depth analysis, the individual frequencies of each drug were identified. Given the significant number of prescribed drugs, those present in at least $5 \%$ of prescriptions (Table 4) were highlighted. 
Table 4 - Most frequently prescribed medications via oral and gastrointestinal catheter in the Walk-in Service - Rio Grande, RS, Brazil, 2017.

\begin{tabular}{|c|c|c|c|c|c|c|c|c|c|c|c|}
\hline \multirow{2}{*}{ Medication } & \multirow{2}{*}{$\begin{array}{l}\text { Frequency } \\
\text { (n) }\end{array}$} & \multirow{2}{*}{$\begin{array}{l}\text { Percentage } \\
\quad(\%)\end{array}$} & \multicolumn{3}{|c|}{ Administration route $(\mathrm{n})$} & \multicolumn{6}{|c|}{ Administration regimen (n) } \\
\hline & & & Oral & GIC & Unknown & 1x/day & $12 / 12 \mathrm{~h}$ & $8 / 8 \mathrm{~h}$ & $6 / 6 h$ & $7 / 7 \mathrm{~d}$ & Unknown \\
\hline Omeprazole & 227 & 40 & 224 & 2 & 1 & 208 & 17 & - & 1 & 1 & - \\
\hline Prednisone & 75 & 13.2 & 75 & - & - & 47 & 26 & 1 & - & - & 1 \\
\hline Simvastatin & 74 & 13 & 69 & 2 & 3 & 71 & 1 & - & - & - & 2 \\
\hline Furosemide & 72 & 12.7 & 70 & 2 & - & 56 & 11 & 5 & - & - & - \\
\hline Enalapril & 64 & 11.3 & 63 & - & 1 & 13 & 49 & 1 & - & - & 1 \\
\hline Hydrochlorothiazide & 62 & 10.9 & 62 & - & - & 60 & 1 & 1 & - & - & - \\
\hline Captopril & 57 & 10 & 54 & 2 & 1 & 2 & 11 & 44 & - & - & - \\
\hline Spironolactone & 51 & 9 & 50 & 1 & - & 47 & 3 & - & 1 & - & - \\
\hline Lactulose & 50 & 8.8 & 49 & 1 & - & 3 & 6 & 37 & 4 & - & - \\
\hline Losartan & 49 & 8.6 & 49 & - & - & 20 & 25 & 4 & - & - & - \\
\hline Clarithromycin & 46 & 8.1 & 46 & - & - & 46 & - & - & - & - & - \\
\hline $\begin{array}{l}\text { Sulfamethoxazole + } \\
\text { Trimethoprim }\end{array}$ & 41 & 7.2 & 31 & - & 10 & 31 & - & - & - & - & 10 \\
\hline Metformin & 37 & 6.5 & 37 & - & - & 5 & 12 & 18 & 2 & - & - \\
\hline Propranolol & 36 & 6.3 & 35 & 1 & - & 7 & 23 & 6 & - & - & - \\
\hline AAS Buffered & 33 & 5.8 & 32 & - & 1 & 33 & - & - & - & - & - \\
\hline Pyrimethamine & 33 & 5.8 & 31 & 1 & 1 & 29 & - & 4 & - & - & - \\
\hline Folinic acid & 31 & 5.5 & 30 & - & - & 31 & - & - & - & - & - \\
\hline Azithromycin & 29 & 5.1 & 28 & 1 & - & 17 & 1 & - & - & 10 & 1 \\
\hline Mineral oil & 29 & 5.1 & 28 & 1 & - & 2 & 4 & 20 & 2 & - & 1 \\
\hline
\end{tabular}

Omeprazole, an anti-ulcer drug that acts by reducing the acidic secretion of the stomach, was the most prescribed in the service in that period. Of the other most frequently prescribed drugs, four are anti-infective and nine are from the cardiovascular action group.

Because of illegibility, lack of standardization of doses and names in the analyzed prescriptions, 14 medications were not included in the quantitative of individual frequencies. In ten prescriptions, the medication Sulfamethoxazole + Trimethoprim was incomplete in relation to the prescribed dose, which prevented a more detailed analysis. Similarly, the medications Simvastatin (two prescriptions), Enalapril (one prescription) and Sodium Valproate (one prescription) had a prescription error, therefore, it was not possible to identify the prescribed dose.

\section{DISCUSSION}

The study site attends patients in situations of urgency or emergency with varied pathologies and who undergo several procedures. Even though it is not an inpatient unit, the Walk-in Service is overcrowded because patients remain in this place until they are transferred to another unit. The high number of patients exceeds the tolerated demand, which can compromise the quality of care. The National Health Surveillance Agency (Portuguese acronym: ANVISA - Agência Nacional de Vigilância Sanitária) published the Bulletin of Patient Safety and Quality in Services. It showed that the highest number of incidents in health services has occurred during the category of care provision (93.6\%), involving diagnosis, evaluation, treatment or surgical intervention ${ }^{(12)}$. In this investigation, it was also mentioned that in 2015, hospital incidents corresponded to $93.2 \%$ of notifications, and the exclusive urgency and emergency service was in second place with $2.7 \%$ of notifications.

In this study, there was a predominance of drugs in solid form, corroborating other studies of drug profiles administered by catheters performed in teaching hospitals in the country ${ }^{(13-16)}$. Although liquid formulations are preferred for administration via GI route, publications show the need for adaptation of drugs in the preparation of medicines by this route. The availability of oral medications, associated with low cost compared to the use of parenteral route justifies this choice. However, most solid drugs are not formulated for administration via GI route and this may affect their efficacy and/or cause drug toxicity with potential risk for the development of adverse events $^{(17-18)}$. Authors of a study conducted at a University Hospital of Paraná in 2016 cited the inappropriate medications that are most prescribed for enteral route, many of which are in this study: Lactulose, Captopril, Phenytoin, Ranitidine, Omeprazole, Complex B, Folic Acid, Tramadol, Bromopride and Nifedipine ${ }^{(19)}$.

For optimization of patient safety, each medication must be evaluated for specific suitability depending on the route to be used. Ideally, all medications should be 
presented to nurses in the final dosage formulation for administration, although practice does not confirm this premise. According to the guidelines of the American Society for Parenteral and Enteral Nutrition (ASPEN) ${ }^{(9)}$, some general precautions should be considered, as follows: check correct positioning of catheter, always wash catheter before and after each administration with at least $15 \mathrm{ml}$ of water to avoid obstruction, pause enteral nutrition for at least 30 minutes before and after administration, administer each medicament separately and never add medicaments in enteral formulas in order to avoid physical and chemical incompatibilities, obstruction and altered therapeutic responses, and in cases of solutions or suspensions, dilution may be necessary for reducing the viscosity or osmolarity of the $\operatorname{drug}^{(9-10,17,20)}$.

The specificities of each drug must be verified in order to perform a differentiated care. Simple tablets, which appeared in greater numbers in this and other studies ${ }^{(13,16)}$, should be crushed until becoming a fine powder that must be mixed with sterile water, or may also be placed in a syringe with sterile water until completely dissolved. Soft capsules may be punctured at one end to remove their contents, which should be mixed with water. However, this method may result in incomplete removal and consequent underdosing. Another way is to dissolve the soft capsule in warm water and administer it with care not to administer the undissolved portion of the gelatin. Medicines of prolonged-release, enteric coating or microencapsulated products are unsuitable for use via GI catheter because they compromise the controlled release of the active substance ${ }^{(17,20-21)}$. In case of changes in drug pharmacokinetics because they were not administered in the planned form, drug absorption may also change, thus preventing the desired therapy ${ }^{(22)}$.

In this study, the highest number of medication were those of the anti-infective class, with $25.9 \%$ of total drugs prescribed. These are the second drug class with the greatest financial impact for health institutions ${ }^{(23)}$. Within this class, appeared antibacterial, antiparasitic, antifungal, antiviral, and antiseptic drugs, as well as scabicides and pediculicide. Of this group, Clarithromycin, Sulfamethoxazole + Trimethoprim, Pyrimethamine and Azithromycin were the most frequently prescribed drugs. The pharmaceutical form found in the study of Sulfamethoxazole + Trimethoprim and Pyrimethamine was the simple tablet, which, if prepared correctly, has no restriction. On the other hand, Clarithromycin and Azithromycin were prescribed in the form of coated tablets with no indication for grinding if administering via GI catheter, since loss of the coating could inactivate the active principle and obstruct the catheter ${ }^{(23-24)}$. Nevertheless, these criteria are not observed in the prescription. Note that both Azithromycin and Clarithromycin are medications included in the standards of the institution under study and can be replaced for ampoule for intravenous administration. Azithromycin is also available as an oral suspension.

The antimicrobial sulfamethoxazole + trimethoprim also has a high frequency of administration. It is chosen in the prophylaxis and treatment of pneumonia in patients with HIV. Given its mechanism of action, the risk of bacterial resistance is minimized and this may be the reason for choice. This drug appeared in two prescribed dosages $(400+80 \mathrm{mg}$ and $800+160 \mathrm{mg})$. It is highlighted because of errors in ten prescriptions due to lack of dosage that made its distinction impossible. Boullata et al. ${ }^{(17)}$ refer the responsibility for prevention of medication errors must be shared between prescriber, pharmacist and nursing, since interdisciplinary action is fundamental for achieving positive results. Both dosages had the form of simple tablet, but the institution also offers the forms of oral solution and ampoule bottle ${ }^{(24)}$. Therefore, it is suggested the substitution in case of administration via GI catheter.

The class of drugs that act in the cardiovascular system was in second place in the total number of medications, which corroborates other studies ${ }^{(15)}$. Data indicate that, out of the 19 most frequent medications, nine are part of this class. For a few decades, Brazil has had cardiovascular diseases as one of the main causes of mortality because of the increased life expectancy of the population, and hypertension is the main risk factor for these more prevalent diseases ${ }^{(23)}$. Among the highest frequencies, this group of drugs is subdivided into classes of antihypertensives (Enalapril, Captopril and Losartan), diuretics (Furosemide, Hydrochlorothiazide and Spironolactone), antiarrhythmics (Propranolol), antiplatelet (AAS Buffered) and antitilipemic (Simvastatin). The latter is the main representative of statins, the drug with the greatest effectiveness in decreasing lipid concentration ${ }^{(23)}$, and found in greater numbers in this study. As in other studies $^{(16,19)}$, Simvastatin was prescribed in doses of $20 \mathrm{mg}$ and $40 \mathrm{mg}$, and in two prescriptions it was not possible to distinguish the dosage. Its form of presentation was coated tablet, but the simple tablet is already known as an available option for replacement.

Omeprazole was the most prescribed of all drugs in the study in the form of a hard gelatin capsule containing gastro-resistant microgranules. When these microgranules are crushed, they lose the enteric coating hence the gastric acid inactivates the drug. In administration by GI catheter, "the capsule may be opened and the intact granules can be diluted in acid fruit juice, as this will ensure the granules arrive intact in the intestine"(16). Furthermore, drug administration should be done one hour before enteral nutrition, as its absorption is decreased in the presence of food ${ }^{(16,19,21,25)}$.

The anti-inflammatory Prednisone was the second most frequently prescribed drug, present in $13.2 \%$ of prescriptions in simple tablets and for oral use in all administrations. If there is a need for adaptation of the pharmaceutical form to the catheter route, tablet grinding is allowed as long as followed by administration with 15 to $30 \mathrm{ml}$ of water. However, we suggest evaluating the "alternative use of injectable solution of Methylprednisolone or oral solution of Prednisolone according to the equivalence conversion"(15). 
Lactulose in the form of syrup was another medication among the most prescribed ones. This osmotic laxative is an example of a liquid formulation with osmolarity of about $3,000 \mathrm{mOsm} / \mathrm{kg}$, which needs to be diluted in an appropriate volume of water (10 to $100 \mathrm{ml}$ ), for easier administration via GI catheter ${ }^{(23)}$. Normally, syrups are considered as physically incompatible with enteral nutrition and require separate administration. Another important care is the monitoring of patients' blood pressure and hydration. As the medicine may contain galactose or lactose, glycemia should be monitored in diabetic patients.

Despite the several barriers - prescribing, scheduling, dispensing, preparing and administering medication -, the error can reach the patient, given the lack of knowledge of the professionals involved. In recent years, medication errors have been identified as determining factors for potential harm to patients. Therefore, it is highlighted the importance of discussing the theme from the present study results, as well as developing continuing education programs for the updating of professionals responsible for such care. In this context, the importance of nurses' role as leaders of the health team is emphasized. They should provide training to professionals and integrate the multidisciplinary team in the stages of care. Labels with warnings that certain medicines cannot be grinded, and tables with alternatives for replacing solid forms with liquid forms are some possible ways of preventing errors when GI catheter route is required. Risk situations related to patient care must be highlighted and always reviewed with all those responsible for the medication process.

Data collection only with records from prescriptions without checking each patient is considered a fragility of the present study. Thus, many outdated prescriptions might not present the actual route of administration in use. In addition, due to the illegibility, incompleteness and incomprehension of some prescriptions, it was not possible to distinguish the data referring to some medications, thus characterizing a prescription error.

\section{CONCLUSION}

The results of this study demonstrated that all drugs prescribed for catheter administration were in solid form, which, according to the literature, is not considered preferential. Even though there is little record of use of catheter route, this can be the route of choice in case of worsening of patients' clinical conditions in Walk-in Services, particularly when the patient is under a temporary hospitalization system until finding a place in the respective treatment unit. Hence, this shows that the care recommended in the literature is not always performed in direct patient care.

Anti-infective drugs were the most prescribed, along with drugs acting in the cardiovascular system. The most prominent drug, however, was omeprazole with the highest number of prescriptions, most of them in the once a day regimen.

The study showed the need for greater legibility in medical prescriptions, substitution options available in the pharmacy, and institutional protocols with exclusive recommendations for the preparation and administration of medications via GI catheter. Manufacturers should also have the obligation to better explain the care and restrictions in the different routes of administration, since it was difficult to find more specific recommendations.

Regarding the applicability and implications of the study results in hospital care practice, this study can contribute to the multiplication of knowledge by enabling a better performance of the nursing team activities, and assisting health teams with maintaining patient safety in the hospital environment.

The health team involved in the entire medication process needs to be constantly updated through continuing education about scientific and technical knowledge in the steps to be followed. There must be multiprofessional commitment in this task that requires cooperation from different areas.

\section{RESUMO}

Objetivo: Identificar o perfil dos medicamentos prescritos por via oral e por sonda gastroenteral, em um Serviço de Pronto Atendimento de um Hospital Universitário. Método: Pesquisa quantitativa, do tipo transversal, na qual os dados foram coletados nos prontuários dos pacientes internados que utilizavam medicações via oral ou por sonda gastroenteral, pelo menos uma vez ao dia, entre abril e outubro de 2015. A análise foi realizada por meio de estatística descritiva. Resultados: De um total de 568 prescrições, havia 143 medicamentos diferentes. A forma farmacêutica com maior número de apresentações foi a sólida (95,8\%), 46,1\% delas em comprimido simples, e a via oral foi responsável pelo maior número de administrações (97,3\%). O grupo de medicamentos mais prescrito foram os anti-infecciosos $(25,9 \%)$, mas o fármaco Omeprazol foi o mais prescrito no estudo (40\%). Conclusão: Há indicativos que possibilitam repensar a prática do cuidado e estabelecer critérios e normas que contribuam para a segurança e a eficácia dos serviços prestados nos serviços em saúde, em especial, no que se refere ao preparo e à administração dos medicamentos via sonda gastroenteral.

\section{DESCRITORES}

Nutrição Enteral; Segurança do Paciente; Interações Medicamentosas; Interações Alimento-Droga; Cuidados de Enfermagem.

\section{RESUMEN}

Objetivo: Identificar el perfil de los fármacos prescritos por vía oral y por sonda gastroentérica, en un Servicio de Urgencias de un Hospital Universitario. Método: Investigación cuantitativa, del tipo transversal, en la que los datos se recogieron en las fichas de los pacientes hospitalizados que utilizaban fármacos por vía oral o por sonda gastroentérica, por lo menos una vez al día, entre abril y octubre de 2015. El análisis fue llevado a cabo mediante estadística descriptiva. Resultados: De un total de 568 prescripciones, había 143 fármacos distintos. La forma farmacéutica con mayor número de presentaciones fue la sólida (95,8\%), el $46,1 \%$ de ellas en comprimido simple, y la vía oral fue responsable del mayor número de administraciones (97,3\%). E1 grupo de fármacos más prescrito fueron los antiinfecciosos $(25,9 \%)$, pero el medicamento Omeprazol fue el más prescrito en el estudio 
(40\%). Conclusión: Hay indicativos que posibilitan repensar la práctica del cuidado y plantear criterios y normas que contribuyan a la seguridad y la efectividad de los servicios prestados en los servicios sanitarios, en especial, en lo que se refiere a la preparación y la administración de los fármacos por vía sonda gastroentérica.

\section{DESCRIPTORES}

Nutrición Enteral; Seguridad del Paciente; Interacciones Medicamentosas; Interacciones Alimento-Droga; Atención de Enfermería.

\section{REFERENCES}

1. Brasil. Ministério da Saúde; Fundação Oswaldo Cruz; Agência Nacional de Vigilância Sanitária. Documento de referência para o Programa Nacional de Segurança do Paciente [Internet]. Brasília; 2014 [citado 2017 out. 10]. Disponível em: http://bvsms.saude.gov.br/ bvs/publicacoes/documento_referencia_programa_nacional_seguranca.pdf

2. Mendes W, Pavão ALB, Martins M, Moura MLO, Travassos C. Características de eventos adversos evitáveis em hospitais do Rio de Janeiro. Rev Assoc Med Bras [Internet]. 2013 [citado 2017 out. 10];59(5):421-8. Disponível em: http://www.scielo.br/pdf/ramb/v59n5/v59n5a06.pdf

3. Sharma S, Tabassum F, Khurana S, Kapoor K. Frontline worker perceptions of medication safety in India. Ther Adv Drug Saf [Internet]. 2016 [cited 2016 Dec 13];7(6):248-60. Available from: https:/www.ncbi.nlm.nih.gov/pmc/articles/PMC5117152/

4. El-Jardali F, Sheikh F, Garcia NA, Jamal D, Abdo A. Patient safety culture in a large teaching hospital in Riyadh: baseline assessment, comparative analysis and opportunities for improvement. BMC Health Serv Res [Internet]. 2014 [cited 2017 Oct 12];14:122. Available from: https://www.ncbi.nlm.nih.gov/pmc/articles/PMC3975247/

5. Xu C, Li G, Ye N, LuY. An intervention to improve inpatient medication management: a before and after study. J Nurs Manag. 2014;22(3):286-94.

6. Teixeira TCA, Cassiani SHB. Root cause analysis of falling accidents and medication errors in hospital. Acta Paul Enferm [Internet]. 2014 [cited 2017 Mar 20];27(2):100-7. Available from: http://www.scielo.br/pdf/ape/v27n2/en_0103-2100-ape-27-02-0100.pdf

7. Moriel P, Shoji P, Bortoletto TC, Mazzola PG. Uso offlabel de medicamentos através de sondas: divergência entre informações. Rev Bras Farm Hosp Serv Saúde [Internet]. 2012 [citado 2017 set.16];3(2):20-4. Disponível em: http://www.sbrafh.org.br/rbfhss/public/ artigos/2012030204BR.pdf

8. Pena MM, Braga AT, Meireles ES, Vassao LGC, Melleiro MM. Mapeamento dos erros de medicação em um hospital universitário. Rev Enferm UERJ [Internet]. 2016 [citado 2016 jun];24(3):e7095. DOI: http://dx.doi.org/10.12957/reuerj.2016.7095

9. Ferracini FT, Marra AR, Schvartsman C, Santos OF, Victor ES, Negrini NM, et al. Using Positive Deviance to reduce medication errors in a tertiary care hospital. BMC Pharmacol Toxicol [Internet]. 2016 [cited 2016 Dec 13];17(1):36. Available from: https://www.ncbi.nlm.nih. gov/pmc/articles/PMC4976064/

10. Bankhead R, Boullata J, Brantley S, Corkins M, Guenter P, Krenitsky J, et al. Enteral nutricion practice recommendations. JPEN J Parenter Enteral Nutr. 2009;33(2):122-67.

11. Polit DF, Beck CT, Hungler BP. Fundamentos de pesquisa em enfermagem: métodos, avaliação e utilização. $5^{\mathrm{a}}$ ed. Porto Alegre: Artmed ; 2011.

12. Brasil. Ministério da Saúde; Agência Nacional de Vigilância Sanitária. Boletim Segurança do Paciente e Qualidade em Serviços de Saúde. Incidentes relacionados à assistência à saúde [Internet]. Brasília; 2016 [citado 2017 out. 10];(16). Disponível em: https://www20.anvisa. gov.br/segurancadopaciente/

13. Silva MFB, Brito PD, Guaraldo L. Oral drugs at a hospital unit: adequacy for use via enteral feeding tubes. Rev Bras Enferm [Internet]. 2016;69(5):795-801. DOI: http://dx.doi.org/10.1590/0034-7167-2015-0081

14. Martins MR, Soares AQ, Modesto ACF, Carvalho RF, Melo VV, Duarte IP. Análise de medicamentos administrados por sonda em unidades de terapia intensiva em hospital de ensino. Rev Eletr Enf [Internet]. 2013 [citado 2017 out. 27]15(1):191-6.. Disponível em: https://www. fen.ufg.br/revista/v15/n1/pdf/v15n1a22.pdf

15. Basso AP, Pinheiro MS. Avaliação dos medicamentos prescritos para pacientes submetidos à terapia nutricional enteral no CTI. Rev Bras Farm Hosp Serv Saúde [Internet]. 2014 [citado 2017 out. 6];5(1):12-8. Disponível em: http://www.sbrafh.org.br/rbfhss/public/ artigos/2014050102000471BR.pdf

16. Rodrigues JB, Martins FJ, Raposo NRB, Chicourel EL. Perfil de utilização de medicamentos por sonda enteral em pacientes de um hospital universitário. Rev Bras Farm Hosp Serv Saúde [Internet]. 2014 [citado 2017 out. 6];5(3):23-7. Disponível em: http://www.sbrafh.org.br/ rbfhss/public/artigos/2014050305000592BR.pdf

17. Boullata JI, Carrera AL, Harvey L, Escuro AA, Hudson L, Mays A et al. ASPEN safe practices for enteral nutrition therapy. JPEN J Parenter Enteral Nutr. 2017;41(1):15-103. DOI: 10.1177/0148607116673053

18. Dabaghzadeh F, Rashidian A, Torkamandi H, Alahyari S, Hanafi S, Farsaei S, et al. Medication errors in an emergency department in a large teaching hospital in Tehran. Iran J Pharm Res. [Internet]. 2013 [cited 2017 Oct 6];12(4):937-42. Available from: https://www.ncbi. nlm.nih.gov/pmc/articles/PMC3920714/

19. Godoi KEP, Penteado STS, Mendes AEM, Andrzejevski VMS. Medicamentos via sonda: perfil prático em um hospital terciário de ensino. Rev Bras Farm Hosp Serv Saúde [Internet]. 2016 [citado 2017 out. 27];7(3):13-18. Disponível em: http://www.sbrafh.org.br/rbfhss/public/ artigos/2016070302000941BR.pdf

20. Hoefler R, Vidal JS. Administração de medicamentos por sonda. Bol Farmacoter [Internet]. 2009 [citado 2017 out. 6];14(3-4):1-6. Disponível em: http://www.cff.org.br/sistemas/geral/revista/pdf/122/063a068_farmacoterapeutica.pdf

21. White R, Bradnam V. Handbook of drug administration via enteral feeding tubes. 3th ed. Londres: Royal Pharmaceutical Society of Great Britain; 2015

22. Ferreira Neto CJB, Plodek CK, Soares FK, Andrade RA, Teleginski F, Rocha MD. Pharmaceutical interventions in medications prescribed for administration via enteral tubes in a teaching hospital. Rev Latino Am Enfermagem [Internet]. 2016 [cited 2017 Oct 6];24(26):1-9. Available from: http://www.scielo.br/scielo.php?script=sci_arttext\&pid=S0104-11692016000100329 
23. Brasil. Ministério da Saúde; Secretaria de Ciência, Tecnologia e Insumos Estratégicos, Departamento de Assistência Farmacêutica e Insumos Estratégicos. Formulário terapêutico nacional 2010: Rename 2010 [Internet]. Brasília; 2010 [citado 2016 out. 6]. Disponível em: http:// bvsms.saude.gov.br/bvs/publicacoes/formulario_terapeutico_nacional_2010.pdf

24. Brasil. Ministério da Saúde; Agência Nacional de Vigilância Sanitária. Bulário eletrônico [Internet]. Brasília; 2013 [citado 2017 out. 6]. Disponível em: http://www.anvisa.gov.br/datavisa/fila_bula/index.asp

25. Lopes DMA, Gomes EV, Madeira LS, Aguiar MCR. Revisão sobre o uso de fármacos através de sondas digestivas: um estudo de base hospitalar. Rev Bras Farm Hosp Serv Saúde [Internet]. 2013 [citado 2017 out. 6];4(2):6-13. Disponível em: http://www.sbrafh.org.br/rbfhss/ public/artigos/2013040201000296BR.pdf 